\title{
MOBILE LEARNING: TOOLS AND SERVICES, FUNCTIONS AND OPPORTUNITIES
}

\author{
Vera I. Toktarova ${ }^{1 *}$ and Anna E. Shpak ${ }^{2}$ \\ ${ }^{1}$ Assoc. Prof., PhD, Mari State University, Russia, toktarova@yandex.ru \\ ${ }^{2}$ Senior Lecturer, Mari State University, Russia, annanemova@yandex.ru \\ ${ }^{*}$ Corresponding Author
}

\begin{abstract}
The relevance of the research is conditioned by the increasing role of the use of mobile learning technologies and services in the educational process of higher educational institutions. The article discusses the issues related to the role of mobile learning in the formation of a new educational environment. It presents the analysis of the main formation and development stages for the mobile learning system, its legislative form and development prospects. The research identifies the reasons that hinder the development of mobile learning in Russia and the factors contributing to its spread. The authors consider tools and services of mobile learning from the point of view of target and functional purpose. They describe the advantages and disadvantages of the use of these tools and services in teaching students.
\end{abstract}

Keywords: mobile learning (m-learning), mobile technologies, mobile services, mobility, educational process, higher education, student.

\section{INTRODUCTION}

Modern society is developing rapidly, that is why the requirements for professional education are also changing. In the world, the educational space shows an increased interest in the development, application and management of various innovative processes, one of which is the active use of mobile technologies and services.

The rate of the mobile communication market expansion is known to be rapidly increasing from year to year. According to the global Digital 2020 report (DIGITAL, 2020), more than 5.19 billion people use mobile phones which shows an increase of 124 million (2.4\%) during one year, while the number of Internet users in the world has increased up to 4.54 billion, which is $7 \%$ more than the last year's figure. In accordance with the statistical data of Statcounter (Global Stats, 2020), about $53 \%$ of all requests on the Internet are made from mobile devices, and this figure is growing every year. Thanks to this, mobile technologies inevitably penetrate not only into all spheres of life, but also into the educational sphere, offering a holistic approach to the organization of the educational environment of higher educational institutions.

Mobile technologies, being a type of information technologies, provide a wide range of opportunities that were previously unavailable. It should be admitted that the universities are often conservative; as a result, there is no stimulating effect on students to make them active user of mobile technology products - laptops, tablets, cell phones. But at the same time, the students, being a part of society which is most receptive to everything new, are known to use these devices most often, and this allows their spreading more widely (Shubina, 2016).

International experience in the use of mobile technologies in education is presented in the UNESCO policy 
guidelines for mobile learning (UNESCO, 2015). The document provides a fairly complete definition of the term "mobile learning", which implies the use of mobile technology both separately and together with other information and communication technologies (ICT), for the organization of the educational process, regardless of place and time.

At the same time, the main advantages of mobile learning, which are confirmed by international research and practice, include:

- Expanding opportunities and ensuring equal access to education (including assistance to students with disabilities);

- Learning anytime and anywhere, providing a link between formal and non-formal education;

- Providing a personalized approach to learning; diagnosis and taking into account individual characteristics and preferences of a student;

- Creating personal educational space and forming new communities of students;

- Improving the quality of communication and management: instant feedback and evaluation of learning outcomes, constant communication with the teacher and the learning community;

- Maximizing cost efficiency.

The use of mobile technologies in education has been studied by many scientists. Some focused their attention on the theoretical and historical, as well as methodological foundations of mobile learning (T. Anderson, S. Wexler, Yu.V. Isaeva, S.L. Lobacheva, A.M. Merkulov, D.V. Pogulyaev, V.I. Soldatkina, E.S. Tikhomirova, etc.); others considered the possibilities and principles of using portable personal devices in training (A.A. Andreev, V.V. Zhukov, E.D. Patarakin, S.V. Titova, etc.). Some authors conducted their research in the field of development and application of mobile learning (D. Attevel, S. Wexler, S.V. Kuvshinov, J. Traxler, S.V. Titova, A.A. Fedoseev, etc.); others considered prospects and opportunities of mobile learning (A. Kay, A.M. Merkulov, J. Traxler, M. Sharples, etc.).

The main purpose of this research is to study the issues related to the role of mobile learning in the formation of a new educational environment of higher education institutions.

\section{CONTENT ANALYSIS OF THE CONCEPT OF "MOBILE LEARNING»}

The use of mobile technologies in the educational process was named "m-learning" or "mobile learning". The term m-learning (mobile-learning) explains the features of using devices such as mobile phones, tablets and laptops in the educational environment. Mobile devices allow students to access the Internet in the same way as desktop computers, while the devices themselves are often cheaper, and are much more convenient in everyday life due to their small size. Mobile learning technology provides for the transfer and receipt of data using GPRS or WAP mobile technologies. Data is stored and processed on a portable individual device, so the owner always has it at hand, unlike in the situation with the desktop computers. The well-known international project MoLeNet (Mobile Learning Network) considers m-learning to be a type of training that uses constantly available devices with an access to the Internet. These parameters - constant availability and access to the Internet - are the key ones for mobile learning (MoLeNET, 2020).

The analysis of Russian and foreign pedagogical studies devoted to the definition of the "mobile learning" concept shows that today there are different approaches to its definition and there is a significant number of relevant interpretations. Let us take a closer look at some of them (table).

Table 1. Definitions of "mobile learning"

Mobile learning is ...

S. Wexler et al. (2007) any activity that allows individuals to be more productive when consuming, interacting with, or creating information, mediated through a compact digital portable device that the individual carries on a regular basis, has reliable connectivity, and fits in a pocket or purse.

I.N. Golitsyna,

N.L. Polovnikova

a type of distance learning, for the implementation of which knowledge is transmitted through personal mobile devices (phone or pocket computer) 


\begin{tabular}{|l|l|}
\hline (2011) & $\begin{array}{l}\text { using WAP or GPRS technologies (that is the possibility to access the } \\
\text { Internet) }\end{array}$ \\
\hline $\begin{array}{l}\text { GOST R 52653-2006 } \\
\text { (2007) }\end{array}$ & $\begin{array}{l}\text { e-learning with the help of mobile devices (smartphones, tablets, netbooks, } \\
\text { communicators, etc.) not limited by student's location }\end{array}$ \\
\hline T.V. Dolgova (2020) & $\begin{array}{l}\text { learning with the use of mobile (portable) devices: tablets, smartphones, } \\
\text { netbooks, mini-computers; learning with the possibility for students to } \\
\text { independently choose the time, place, pace and means of training }\end{array}$ \\
\hline V.A. Kuklev (2010) & $\begin{array}{l}\text { e-learning with the help of mobile devices independent of time and place, } \\
\text { using special software on the pedagogic basis of interdisciplinary and } \\
\text { modular approaches }\end{array}$ \\
\hline A.M. Merkulov (2012) & $\begin{array}{l}\text { a new e-learning paradigm; } \\
\text { the intersecting point of mobile computing environments and e-learning, } \\
\text { which results in the practice of learning anytime and anywhere }\end{array}$ \\
\hline M.Yu. Novikov (2017) & $\begin{array}{l}\text { a form of educational process in which students' cognitive and practical } \\
\text { activities are implemented using mobile devices and technologies in cases } \\
\text { where it is appropriate from a didactic point of view }\end{array}$ \\
\hline $\begin{array}{l}\text { V. A. Osadchy, } \\
\text { I.V. Muradov, } \\
\text { N.V. Lomonosova } \\
\text { (2016) }\end{array}$ & $\begin{array}{l}\text { active use of mobile devices in the process of classroom and extracurricular } \\
\text { training, based on technologies of augmented reality and functioning on the } \\
\text { basis of educational applications }\end{array}$ \\
\hline D.V. Pogulyaev (2006) & $\begin{array}{l}\text { a form of arranging the educational process based on the use of mobile } \\
\text { computer devices and wireless communication }\end{array}$ \\
\hline L.V. Sardak (2016) & $\begin{array}{l}\text { training in a mobile electronic educational environment that does not } \\
\text { depend on the geographical location of a student on the basis of hardware } \\
\text { and software independent platforms }\end{array}$ \\
\hline $\begin{array}{l}\text { S.V. Titova (2012) } \\
\text { transmitting and receiving educational information using WAP or GPRS } \\
\text { technologies to any portable mobile device, which gives an access to the } \\
\text { Internet, allows getting or finding materials, answering questions in the } \\
\text { forum, taking a test, etc. }\end{array}$ \\
\hline
\end{tabular}

The main characteristic of mobile learning is its principle - "at any time and in any place" which emphasizes the "mobility" feature of this type of learning. In turn, personal mobile devices make it possible to implement such type of learning.

Content analysis of the definitions of "mobile learning" revealed two main approaches to its interpretation, reflecting software and technical or didactic / methodological characteristics.

The concepts related to the first approach differ only in the enumeration of mobile communication devices and their technological capabilities, but they do not contain methodological and didactic aspects. However, they can be combined in two main points: mobile training is carried out using mobile portable devices; mobile training involves access to the Internet. These properties determine the main difference between mobile and other types of training.

The second approach pays attention to improving the efficiency, quality and optimization of the learning processes, expanding the arrangement, modes, and methods of training. Some works note the possibility to form competencies in the field of acquiring and processing educational information, others underline the need to adjust the approaches, methods and content of training (Toktarova \& etc., 2015). 


\section{RETROSPECTIVE ANALYSIS OF THE FORMATION AND DEVELOPMENT OF MOBILE LEARNING}

For Russian education, the term "mobile learning" is relatively new and still quite controversial. In the initial studies, the attention was focused on the mobility of both devices (any mobile means and network technologies) and students (they can be in or outside the classroom during training, they can move and work in different teams). At the same time, the educational practice considered different types of classes: traditional, "park", "museum", "theater", etc.

Further, the introduction of the Federal State Educational Standard of Higher Education and the wide spread of the competence approach presented mobile learning as a special form of organizing training using mobile technologies, combining the possibilities of classroom and extracurricular learning activities, individual, group and cooperative learning. Among the advantages of mobile learning it is important to highlight the implementation of access to educational information $24 / 7$ and the interaction of students with their portable devices.

Today, mobile devices are becoming more and more multifunctional, they play audio and video materials, recognize oral speech, reading, writing, search for information, perform calculations and others. The choice of devices depends on both age, functional tasks and other factors. The use of mobile technologies makes training more flexible. Students have the opportunity to keep in touch with the teacher and with each other, to exchange information using messengers, social networks and e-mail, to work on various cooperative projects. Moreover, the use of mobile technologies allows involving into training the students who did not prove themselves in the traditional format.

But at the same time, there are obvious disadvantages of using mobile devices in training: small screen size, which is essential for people with vision problems; need to constantly recharge the battery; rapid obsolescence of mobile devices which can cause problems with using modern programs, browsers and applications; inconvenience of working with graphic materials.

The problems of mobile learning development in Russia and in the world include the following:

- Organizational: experienced teachers are afraid of losing control of the educational process, which in mobile learning occurs at the initiative of the student outside the classroom;

- Competency-based: development of mobile applications requires advanced training or involvement of specialists; insufficient competence of teachers to use mobile learning and communication services;

- Regulatory and legal: uncertainty regarding copyright in electronic data, which makes it difficult to generate educational information that can be reproduced from mobile devices:

- Technical: the need to recharge a mobile device for long-term use; insufficient distribution of existing broadband technologies in the areas with low population density, for example, in rural areas;

- Financial and economic: adding the cost of connecting to a high-speed mobile network to the cost of the mobile device itself.

Even taking into account all the shortcomings and problems of introducing mobile learning in the educational process, mobile learning is now recognized as a new learning environment, independent of the time and location of the student. In 2020, it showed high demand and application efficiency while implementing training in the situation of Covid-19 spreading. Mobile learning has made it possible to almost completely abandon the organizational limitations peculiar for the traditional education without losing the functionality of the training tools used; to remove psychological and organizational barriers.

\section{ANALYSIS OF MOBILE LEARNING TOOLS AND SERVICES}

Mobile learning today is not only one of the types of e-learning, but also a separate form based on access to various educational resources and the arrangement of interactive communication in the conditions of electronic educational environment of higher educational institution. To fully support mobile learning, we have integrated a number of mobile services:

- Services of planning and support of educational activities (online schedule; electronic registration for academic subjects, programs and events; calendar planning; electronic portfolio; tracking of current progress; setting deadlines and credit minimums; electronic library card; application store and educational content, etc.); 
- Services of arrangement and support of educational activities (online educational content for lectures, laboratory, practical and seminar classes, independent work; diagnostics of students' individual characteristics and abilities; selection of optimal training scenario; formation of individual educational trajectories; control and evaluation of the quality of training; management of the learning process of students; implementation of joint research and project activities, etc.);

- Services of communication and feedback (interactive communication of the subjects of learning; formation of educational communities; management of events; organization of webinars and video conferences; group training / research / project activities through collaboration services; conducting surveys and voting through a mobile device, etc.);

- General information services (directories of rooms, contacts, events; information about the official services of the university, mass notification services; notification to the mobile phone in case of an emergency, etc.).

As part of the experimental study, we conducted a survey on the functional significance of mobile technologies introduction into the educational process among students, teachers and administrative staff of the Mari state University.

The survey among students showed that $98.78 \%$ of them highlight the absence of time and geographical restrictions as the main advantage of the introduction of mobile technologies in education, $92.68 \%$ of respondents said that a mobile device is convenient to use for searching for educational information on the Internet. In addition, $87.8 \%$ of students noted that mobile technologies have expanded communication opportunities both among fellow students and through feedback from the teacher, and $84.15 \%$ believe that mobile technologies based on cloud services help to organize group activities and joint work on documents. According to $97.6 \%$ of students, the ability to download educational material to a mobile device also facilitates the learning process, $75.6 \%$ of respondents expressed a desire to receive training in a mobile form.

The results of the survey among teachers showed that $96.15 \%$ of teachers highlighted mobility and efficiency of the organization of the learning process for students; $92.31 \%$ of respondents indicated the availability of resources of the electronic educational environment in any place and at any time. $80.77 \%$ of the teaching staff noted an increase in the efficiency of planning and monitoring the process of teaching students using mobile technologies and ensuring cooperation and interaction of the subjects of mobile learning.

The administrative staff of the university participating in the survey on the functional significance of introducing mobile technologies in the educational process showed slightly lower figures, but they (88.8\%) note an increase in management efficiency by receiving operational feedback and meeting strategic KPIs established by modern requirements for universities and ratings.

$90.7 \%$ of students and teachers stated the need to develop mobile applications and their implementation in the educational process of the university; $66.7 \%$ of administrative staff of the university supported the idea of creating a "mobile" university campus, which will increase the scale and reach greater coverage of students involved in educational and extracurricular activities, and increase the share of students satisfied with educational activities. And $73.2 \%$ of IT students expressed a desire to become specialists in the development of mobile applications in the future.

\section{CONCLUSION}

Thus, mobile learning is a new educational technology that serves the basis for creating a learning environment where students can access learning materials anytime, anywhere, which makes the learning process comprehensive and motivate students to follow the idea of lifelong learning. The results of the content analysis of the "mobile learning" concept revealed two main approaches of its development based on the software and technical or didactic / methodological characteristics of this type of training.

Mobile devices allow overcoming almost completely the organizational limits peculiar to the traditional education, without losing the functionality of the training tools used; they allow to remove psychological and organizational barriers and get access to the electronic educational environment at any time. At the same time, the problems of rapid and effective development of mobile learning in Russia and in the world include a number of obstacles related to organizational, competence, regulatory, technical, and financial and economic constraints.

Training using mobile technologies is carried out within student's free time, and the educational strategy shall be adapted to student's personal needs, characteristics, and interests. To fully support mobile learning at 
the university, we have integrated a number of mobile services, including services for planning and supporting educational activities, services for organizing and supporting educational activities, communication and feedback services, as well as general information services. Experimental results of the study on the need and importance of mobile technologies introduction into the educational process among students, teachers and administrative staff of the university showed high / above average values.

\section{REFERENCE LIST}

DIGITAL 2020: a global overview of digital technologies (2020). https://datareportal.com/reports/digital-2020global-digital-overview

Dolgova T.V. (2020). Mobile learning in a modern school. https://metod.mob-edu.ru/mobilnoe-obuchenie-vsovremennoj-shkole/

Global Stats (2020). https://gs.statcounter.com/platform-market-share/desktop-mobile-tablet

Golitsyna, I.N. and Polovnikova, N.L. (2011). Mobile learning as a new technology in education. Educational technologies and society, 1.

GOST R 52653-2006. (2007). Information and communication technologies in education: terms and definitions. - Moscow: Standartinform

Kuklev, V.A. (2010). Formation of the mobile learning system in open distance education: abstract of a thesis. Doctor of Pedagogical Sciences.

Lomonosova, N.V., Muradov, I.V. and Osadchy, V.A. (2016). Problems and prospects of developing the electronic educational resources from the point of view of mixed training of the university students. New science: problems and prospects. Sterlitamak: RITS AMI.

Merkulov, A.M. (2012). Training with the help of mobile devices - a new paradigm of e-learning. Young Scientist, 3.

Novikov, M.Yu. (2017). The opportunities of mobile technologies in the school course of Computer Science. Pedagogical Education in Russia, 6.

Pogulyaev, D.V. (2006). Possibilities of using mobile technologies in the educational process. Applied Informatics, 5.

Sardak, L.V. (2016). Specifics of electronic educational resources for mobile learning. http://elib.sfukras.ru/handle/2311/30678

Shubina, I.V. (2016). Mobile technologies in the organization of the educational and scientific environment of the university. Young Scientist, 7.6 (111.6).

The Mobile Learning Network (2020). - http://www.molenet.org.uk

Titova, S.V. (2012). Mobile learning today: strategies and the future. Bulletin of Moscow University. Series 19: Linguistics and Cross-Cultural Communication, 1.

Toktarova, V.I., Blagova, A.D., Filatova, A.V. and Kuzmin, N.V. (2015). Design and Implementation of Mobile Learning Tools and Resources in the Modern Educational Environment of University. Review of European Studies, 7 (8).

UNESCO policy guidelines for mobile learning / United Nations Educational, Scientific and Cultural Organization (2015). http://iite.unesco.org/files/news/639198/ISBN_978-92-3-400004-8.pdf

Wexler, S. Schlenker, B., Brown, J., Metcalf, D., Quinn, C., Thor, E., Van Barneveld, A. and Wagner, E. (2007). 360 research report mobile learning: What it is, why it matters, and how to incorporate it into your learning strategy. Santa Rosa, CA: eLearning Guild. 